\title{
The Governance of Islam in Finland ${ }^{1}$
}

\author{
TUOMAS MARTIKAINEN \\ Åbo Akademi University
}

\begin{abstract}
Issues related to migration, security and integration are currently among the top priorities of European states. Lately, 'religion' has emerged as something separate from 'culture', 'ethnicity', 'nationality' and 'race' in the debate over integration and security. Collective religious activity is among the most common forms of the social organisation of immigrants. Immigrant communities have been analysed from a multiplicity of perspectives, but one area that has until recently received little attention is the relationship between on the one hand the local and national authorities, on the other religious organisations of immigrant origin. Religion, most notably Islam, has been identified as a social problem among the public authorities in Europe. The article provides a critical viewpoint on the formation of immigrant voluntary associations as authorities' tools of governance. While voluntary associations can be seen as tools for integration and empowerment, they may become embedded in power structures that are not at first glance self-evident. The article argues that the local and national authorities in Finland support and encourage Muslim immigrants to organise themselves into voluntary religious associations, enabling the authorities to better govern issues that have been defined as social problems. The work applies the theory of governmentality as developed by Mitchell Dean, to Muslim organisations in Finland.
\end{abstract}

Keywords: Governance, governmentalisation, Islam, immigration, Muslims, security

Collective religious activity is among the most common forms of social organisation of immigrants in a new social context (Baumann 2002). Buddhist, Christian, Hindu, Muslim, Sikh and other religious communities of immigrant origin flourish in all migration centres (e.g., Eade 1997; Ebaugh

1 This article was originally presented as a paper entitled 'Immigrant Governance through Voluntary Associations' at the EUROFOR Conference, 'National and Local Government Confronted with Cultural Diversity', June 2006, in Maratea, Italy. I would like to thank Petri Hautaniemi, Matthias Koenig, Markus Mervola, Miikka Pyykkönen, Tuula Sakaranaho and Pasi Saukkonen as well as the two anonymous referees for their many valuable comments on the manuscript, which I took into account as far as possible. 
\& Chafetz 2000; Jacobsen \& Kumar 2004; Warner \& Wittner 1998). Since World War II many thousand such organisations have been formed, and more recently they have become of increasing interest to scholars studying contemporary religion and migration. Most of the attention has been devoted to Islam and Muslims (e.g., Haddad \& Smith 2002; Maréchal et al. 2003; Nielsen 1995; Nökel \& Tezcan 2005). These communities have been analysed from a multiplicity of perspectives, including religious activities, gender roles, social networks, transnational connections, identity and so forth (Buijs \& Rath 2005; Stepick 2005).

One area that has received surprisingly little attention is the relationship between the local and national authorities and religious organisations of immigrant origin. The link is often noted, but little analytical effort has been directed at understanding the webs of power relations that are embedded in these encounters. Regarding Muslims in Europe, Brigitte Maréchal (2003a, 176-177) notes that 'European states [...] want to have someone to negotiate with', 'where Islam has been officially recognised, they have helped the process along [...] they [the states] have usually intervened to a fairly great extent'. Furthermore, it can be understood almost as 'a tribal approach [...] to the anxious search for community representatives, underlining that there are no leaders for the majority of the white community, the natives, but there are only leaders of specific interests' (Allievi 2003a, 201; italics in original). During the last few years, however, increasing attention has been directed at analysing the phenomenon (e.g., Bader 2007; JEMS 2007).

This article provides a critical viewpoint on the formation of immigrant voluntary associations as authorities' tools of governance. In my previous studies (e.g., Martikainen 2004a), I have emphasised the role of religious organisations in general in both empowering immigrants and integrating them into Finnish society. At the same time, however, it is equally important to be aware of the efforts of the mainstream society to control its minorities. While voluntary associations can be seen as, and often are, tools for integration and empowerment, under certain conditions they may produce the opposite effect, or at least create power structures that are not transparent or obvious. In this article, I argue that the local and national authorities in Finland support and encourage Muslim immigrants to organise themselves into voluntary associations and religious communities, so that - among other results - it will be easier for the authorities to govern issues that have been defined as social problems. I am not arguing that this is the only reason the authorities are interested in these organisations; the point I am making is that the creation of power relations is part of a larger picture. The article is based 
on my studies of religious organisations in Finland (e.g., Martikainen 2000; 2004a), and takes into account other national studies in the field of voluntary migrant associations (e.g., Saksela 2003; Pyykkönen 2007b). The theoretical background of the study lies in critical approaches to multiculturalism (e.g., Baumann 1999; Kivisto 2002; Sakaranaho 2006) and governmentalisation (Dean 1999; Foucault 1991; Pyykkönen 2007b).

\section{Governance, Multiculturalism and Religion}

According to Foucault $(1991,102)$, governmentality refers to 'the ensemble formed by the institutions, procedures, analyses, and reflections, the calculations and tactics that allow the exercise of this very specific albeit complex form of power, which has as its target a population; as its principal form of knowledge, political economy; and its essential technical means, apparatuses of security'. Foucault's concept of governmentality has been further developed by Mitchell Dean (1999), who has created a framework whereby governmentalisation, governmentality and governance can be empirically analysed. Dean's basic aim is to make visible the logic of governance that might otherwise remain unseen, as the means and forms of governance cannot necessarily be reduced to the commonly identified power structures, institutions and actors. Dean thus aims at making these power relations explicit and open to scrutiny.

According to Dean $(1999,11)$, government can be defined as follows:

Government is any more or less calculated and rational activity, undertaken by a multiplicity of authorities and agencies, employing a variety of techniques and forms of knowledge, that seeks to shape conduct by working through our desires, aspirations, interests and beliefs, for definite but shifting ends and with a diverse set of relatively unpredictable consequences and outcomes.

This definition in itself already points to the vast number of actors working at the same time, perhaps even sharing the same rationality, but ultimately in a setting where the outcomes are difficult to estimate. It is precisely this unpredictability to which we shall return in the concluding part of the article. Governmentalisation is thus the process through which things become subject to rule. The concept of governance refers to the more concrete acts that aim at inducing the logic of government both within the realm of government itself and outside its direct authority, for instance in attempts to shape the aspirations of voluntary associations. 
Following Dean (1999, 9-39), governmentalisation starts with problematisation: something is identified as a problem that needs a solution. This becomes a programme that is in accordance with the local mentality of rule-governmentality. The problem is identified within a particular societal system, such as the realm of culture, education or health care. Once the problem is identified, a strategy, a regime of practices is created. These regimes of practices can be analytically divided into four dimensions: the forms of visibility, the technologies of government, the forms of rationality and the formation of identities. The ultimate aim of the regime of practices is to create a reform: a condition where the perceived problem is solved or under control.

Miikka Pyykkönen (2007a, 209-215) has identified in his study of immigrant voluntary associations in Finland several techniques of governance and self (-governance). The techniques of governance are (1) the associations themselves, (2) the registration of associations, (3) funding, (4) auditing and evaluating, (5) the Finnish Integration Law and its local implementation, and (6) the advancement of 'original cultures'. The techniques of self (-governance) are (7) participation and (8) activity both in ethnically defined social spaces and in government-sponsored programs (education, working internships etc.) to promote the eventual employment and well-being of immigrants. Pyykkönen calls the latter 'the governmental-ethical work on the Self'. ${ }^{2}$ These two sets of ideas provided by Dean and Pyykkönen will form the analytical model in this article; its details are discussed more comprehensively in the analysis.

Issues related to migration, security and integration are currently among the top priorities of most European states (Ireland 2004). According to Peter Kraus (2003), a diversity-sensitive approach to political and social issues is a reality in current European Union member states, despite the various drawbacks of such policies. "Multiculturalism", however willy-nilly, is becoming to some extent the official approach to diversity in the western world' (ibid., 672). But what is multiculturalism? Peter Kivisto $(2002,37)$ distinguishes between pluralist and cosmopolitan views of multiculturalism: the former stresses group boundaries in an essentialist manner, while the latter focuses ultimately on optional ethnicity, valorising the possibility rather than the necessity of ethnic identification. Gerd Baumann (1999, vii) takes a third stance, pointing out that 'multiculturalism is not the old concept of culture

2 Pyykkönen (2007b, 214-215) had three forms of Techniques of the Self of which the one relating to a personal integration plan was left out of this analysis, as it does not apply to voluntary associations. 
multiplied by the number of groups that exist, but a new, and internally plural, praxis of culture applied to oneself and others'. ${ }^{3}$

Recently, 'religion' - as something separate from 'culture', 'ethnicity', 'nationality' and 'race' - has been foregrounded in the discussion of integration, and perhaps above all security, at least at the level of general discussion of the topic (e.g., Klausen 2005; Roy 2004; Tibi 2002). While the Islamic Revolution in Iraq in 1979, the rise of the Christian Right in the US in the 1980s, and the Salman Rushdie affair in 1988 had made it clear that religion had resurfaced as part of the political agenda, it was $9 / 11$ that became the symbolic turning point (Beyer 2006). This general concern also implies that states and other authorities have increasingly needed to identify religious partners for various programmes. Religion, most notably Islam, has been identified as a problem by the public authorities in Europe. Various measures have therefore been taken by the state authorities in order to normalise or neutralise the threat of 'religion' to social cohesion and security. For example, a major attempt by the European Union to reduce tensions between people of different 'cultures' has been to declare the year 2008 as 'The European Year of Intercultural Dialogue', including various programs and forms of funding (EYID 2007).

But what are the meeting points between the public authorities and religious actors? European states have relatively different forms of legislation regarding religion, and its position differs from one society to another, but there are also some parallels (Bader 2007; Byrnes \& Katzenstein 2006; JEMS 2007; Robbers 2005). New religions of all kinds usually organise themselves as some form of voluntary association. Among the common features of the authorities' activities we find the provision of financial support, meeting places and networking as the tools with which local and national authorities attempt to normalise the newcomers and introduce modes of self-governance (Maréchal 2003a, 151-158; 2003c, 149-150). The quest is thus to identify the key actors and policies whereby the public authorities aim at regulating religious behaviour, so that in - the view of the authorities - it supports the common good and enhances social cohesion.

\section{Muslims in Contemporary Finland}

Finland has had a small Muslim community - the so-called Tatar Muslims - since the latter part of the nineteenth century. The Tatars have been a

\footnotetext{
3 There has been extensive discussion of these issues, where notions such as hybridisation and creolisation have been offered as solutions to essentialist or primordial views on culture, ethnicity, etc. (e.g., Featherstone \& Lash 1999; Featherstone et al. 1995; Hannerz 1996).
} 
culturally introvert group and have not experienced any major problems or hostility from the surrounding society for several decades. According to Tapani Harviainen (1999), the Tatars could be named as an example of 'Euro-Islam'. ${ }^{4}$ From the 1960s onward the Finnish Muslim population gradually began to grow; however, it remained numerically insignificant until the 1990s, when their numbers started to increase rapidly. Reasons for this included the growing acceptance of quota refugees and an increase in asylum seeking, but also migration related to marriage, study and work. Since then, the numbers have also grown due to family reunification. This rise in the number of Muslims coincides with the general growth of immigrant population in the country (Sakaranaho et al. 2004). Within the European context of international migration, Finland was until the late 1970s a country of emigration; it was only in the late 1980s that it became a country of immigration (Castles \& Miller 2003; Forsander 2002).

In 2006 there were an estimated total of 40,000 Muslims in Finland, of whom the vast majority are first-generation migrants. ${ }^{5}$ The actual number may eventually be somewhat higher, but there are currently no reliable estimates of the second generation, which would certainly raise the estimate. In any case Muslims form less than one percent of the Finnish population, which is currently (2007) 5.3 million. The Muslim population is also quite heterogeneous, both ethnically and in terms of religious observance. The largest ethnic groups are the Somalis, the Arabs, the Bosnians, the Kosovo Albanians and the Kurds, who together constitute about 80 percent of the Muslim population. Muslims of Finnish background - converts and Tatars - form under five per cent of all Muslims. These internal differences among the Muslim population, however, are seldom present in the public debate (Martikainen 2004b; forthcoming).

Beginning in the early 1990s there have been increased efforts to organise mosque communities and other institutions; thus today there are some forty mosques around the country. Simultaneously, and with the continuing growth of the Muslim population, the local authorities were confronted with a number of specific issues related to a culture and religion with which they were unfamiliar. The local mosque communities soon became important intermediaries for the local authorities in such areas as health-care and education, which include practices and activities that many Muslim parents consider problematic (Lehtinen 2007; Sakaranaho \& Pesonen 1999). The same

\footnotetext{
4 'Euro-Islam' or 'European Islam' are contested terms with a variety of meanings. Basically, they refer to the accommodation of Muslims to European social, political and religious structures and cultures (see AlSayyad \& Castells 2002).

5 Estimating the number of Muslims is a complex task in Finland, as in many other countries. The details of the estimate are explained in detail in Martikainen (forthcoming).
} 
issues - including for instance mixed-gender physical education, religious education and sex education - are common in other western countries as well (Maréchal 2003b).

Among the Finnish population of immigrant origin, Muslims are overrepresented among those who have had difficulty in entering the labour market as well as among other disadvantaged groups. Thus many of them have not gained economic security or other benefits related to work and to a stable position in society (Forsander 2002). It should be obvious that being a 'Muslim' is not central to these difficulties; rather, it is a question of the individual's refugee or asylum-seeker background that underlies such issues as language skills, educational background and economic opportunities (Martikainen 2007). In addition, general attitudes towards non-natives disadvantage many Muslims, as they belong to ethnic or national groups that experience more prejudice and discrimination than certain other such groups (Jaakkola 2005). Even Islam as a religion is considered with more suspicion than most other religions (Kääriäinen et al. 2005, 79). Be that as it may, being a 'Muslim' has become part of the picture, and is also increasingly identified as such. All of this also implies that religious issues and identities are seen as important and are expected to be taken into account beyond the traditional sphere of religious matters in Finnish society.

\section{Problematisation and System Identification}

In Finland, issues related to immigrants have often been defined as social problems, and extensive administrative measures have been taken for instance to combat unemployment, social passivity and discrimination. In addition, the official notion of integration includes ideological support for the maintenance of 'original culture and language', along with full participation in the mainstream society (Lepola 2000; Pyykkönen 2007b). Thus it is a widely shared view among the public authorities that immigrants constitute a problem, in the sense of Mitchell Dean (1999, 27-28). While the above-mentioned problems can be described as soft security threats, related mainly to social cohesion and welfare, there is also the question of hard security threats, including religiously motivated terrorism. ${ }^{6}$ In recent years, 'soft threats' have been linked with the threat of Islamic radicalism and terrorism (Archer 2004). The Finnish Security Police (SUPO) has publicly announced that it is actively monitoring possible extremist tendencies among Finnish Muslims (SUPO 2005). No major threats, however, have so far been made known in public. Bearing in mind the globally shared views of terrorism

${ }_{6}$ I would like to thank the anonymous referee for pointing out this distinction. 
disseminated in the news media in relation to Islam, it is clear that religion and Islam have been identified as part of the problem (e.g., Archer 2004; Männistö 1999; Poole \& Richardson 2006). In this setting, three main objects of rule emerge: the Muslim population, Muslim associations, and perceived religious opinion leaders. ${ }^{7}$

How do the national and local mentalities of rule, governmentalities, see these three subjects? As it is not criminal in Finland to be a Muslim, it is clear that the measures taken need to be consistent with Finnish legislation and bureaucratic practices and with democratic values. The Muslim population has become the target of a plenitude of general socio-political programmes that include different sectors, systems, of society. A key notion of these programmes is the fight against the marginalisation of people of immigrant origin, where education, employment and empowerment are considered major solutions. There is little that is religion-specific in these regimes of practices; they mostly focus on ethnicity, culture and gender (Ruhanen \& Martikainen 2006). For example, the Finnish Internal Security Programme (Ministry of the Interior 2004, 9) names the support of immigrant integration in general as an important element of internal security. The Internal Security Programme, however, is currently under revision, and measures against religious (Islamic) radicalisation play a prominent role in the process. This implies a new line of thought, the scope of which is still open. Previously, it was only in such institutions as school and health-care that certain practices specific to religion (Islam) had emerged. These often included discussions with individual Muslims, but, more importantly, negotiations with Muslim associations and their leaders (Lehtinen 2007). It is to the role of associations that we now turn.

Good dialogue is essential at all levels [of society]. It is good that the Muslim population has its representatives. [...] Then they can bring forth their views in a representative way. (Risto Volanen (2008), State Secretary, Prime Minister's Office; translation by the author.)

Until now the Muslim population as such has not been directly targeted, but the consensus seems to be that, for the time being at least, religious issues are better negotiated with Islamic associations and religious leaders,

\footnotetext{
7 I refer to religious leaders deliberately as 'perceived religious leaders', as there is currently no way to estimate to what extent the individuals in question enjoy authority among the Muslim population in general. For a critical discussion of the issue of the representativity of religious leaders, see Allievi (2003c, 369-414).
} 
as reflected by the above quotation from State Secretary Volanen. Voluntary associations have been the backbone of Finnish civil society for over a century, and they are commonly understood as an important element of representative democracy. In the aftermath of increased international migration to Finland we have witnessed a large wave of migrant organisation; at least 700 immigrant associations have been founded during the last fifteen years. They include cultural, religious, friendship and ethnic associations, as well as multicultural, women's and sport societies. The majority of these associations have been founded by migrants of refugee and asylum-seeker background, even though they are not the majority of migrants (Pyykkönen 2007b; Saksela 2003).

In addition, we have witnessed the large-scale religious organisation of migrant communities. Migrants of Christian and Muslim background, especially, have been active in this endeavour. While Christians have mainly been able to join existing congregations in the Catholic, Orthodox, Lutheran and other Protestant Churches, the Muslims have not had that opportunity. Thus a large number of Muslim organisations have been founded during the last decade. Other religions have also organised, but to a lesser degree. It is also evident that the local authorities have been active in supporting much of this new organisational development; in other words, the authorities have not been mere bystanders but have participated actively in the process. Official organisation is needed for local funding, as well as enhancing the legitimacy of the community as a negotiation partner. As most of the mosque communities suffer from a lack of financing, they use the means available to improve their chances in funding (Martikainen 2004a; forthcoming; Pyykkönen 2007b).

What about the religious leaders, the third subject identified? Even though no systematic data exists, it is clear the religious leaders have been extensively consulted by local and national authorities, the Finnish government, the Finnish Security Police and other institutions interested in integration and security. For instance the President of Finland Tarja Halonen has had meetings with religious leaders, including Muslims, after 9/11, in order to create working relations and enhance the dialogue between cultures (Illman 2006). Religion is indeed seen as an important element of social cohesion.

A recent example of the education of religious leaders is the project entitled Integration - a Multifaith Approach. The project is organised by the International Organization for Migration, which has a regional office in Helsinki. It is being run in Denmark, Finland, Germany, Latvia and the 
United Kingdom, with the aim of enhancing the 'positive integration' of non-EU, foreign-born religious leaders. The project is based on experiences at Monash University in Australia, and has 'emerged as a response to the growing number of foreign-born religious leaders who, due to their specific cultural backgrounds and/or lack of knowledge of the local culture and norms are unable to contribute positively to their own or their communities' integration' (IOM 2007).

Following Dean (1999), the situation can be summed up as follows: Islam and Muslim migrants have been identified as a problem in relation to social cohesion and security. The main objects of rule are the Muslim population in its totality, Muslim associations, and religious leaders. In Finland, Islam has come to be represented by the associations and their leaders. As the issues at stake belong to diverse social systems, a number of different regimes of practices are needed. Beyond the activities of the Finnish Security Police, there are numerous actors in many different sectors and at different levels of society, including education, health-care, integration, prisons and working life (cf. Lehtinen 2007). In order to solve the perceived threats to social cohesion and national security, various regimes of practices have been implemented.

\section{Regimes of Practices}

The first element in Dean's (1999, 30-31) model of analysis of governance is forms of visibility, which can also be understood in a metaphorical sense. To make things 'visible' means that they are identified, including the various actors involved and how they function. In Europe, a crucial role in making Islam and the Muslims visible is played by the media. Islam, for instance, is often presented as a problematic religion in relation to gender equality. The controversies over the hijab would be incomprehensible without the symbolic meanings attached to it. How can a piece of clothing give rise to such anger, pride or attention? On its own it cannot; but through the attached threat directed at gender equality and women's empowerment, the hijab, together with female circumcision (or female genital mutilation/cutting, as many prefer) has been in the foreground of the cultural critique of Islam in the West. The media also implicitly portray terrorists and other extremists as synonymous with all Muslims, by the sheer volume that this theme occupies out of the total media space devoted to mediatised Islam. Reports on attitudes towards Islam and Islamophobia show that the message has been heard (e.g., CBMI 2004; EUMC 2002; 2006; PEW 2006). It is no wonder that many Muslims consider the media as one of their main problems. 
Further factors in identifying Islam as a problem are other visible manifestations of Islam, including religious meeting sites, in particular purpose-built mosques. The numerous 'mosque controversies' in European countries are to a large degree about the symbolic (non-) acceptance of the Religious Other, while the much more numerous but publicly invisible 'backyard mosques' have generated significantly less noise (Allievi 2003b, 343; Maréchal 2003c, 84). The public presence is also visible through organisations that aim at representing local and national interests, and are thus easily identifiable discussion partners. It should be noted, however, that usually only few of these organisations become ongoing partners, while many of them are either uninterested in dialogue or unable to become partners in such networks.

In Finland, the forms of Islam visibility are in line with this description. Much of the media discourse when dealing with Islam is problem-oriented and full of stereotypical images. Among the topics discussed during recent years have been the hijab, female and male circumcision, ritual slaughter and suspicions concerning terrorism, as well as the occasional plans for purpose-built mosques - that so far have not been realised. While there is a lack of research in this field, this is indicated by the few existing studies (Creutz et al. 2002; Männistö 1999; Maasilta et al. 2008; Sakaranaho et al. 2004). One of the results of these and other discussions is that a number of Finnish experts, both Muslim and non-Muslim, have been identified. They act as spokespersons in the media, and, as far as I know also serve as experts on less public occasions. Beyond these, it is clear that local Muslim associations are recognised as representatives of at least some Muslims (Lehtinen 2007). In line with the argument of this article, we can also assume that one of the main preconditions as well as one of the aims of governance is to make the perceived problem more visible so that it can be better identified.

The second regime of practices is the technology of government: 'if government is to achieve ends, or seeks to realize values, it must use technical means' (Dean 1999, 31). Following the techniques of governance identified by Pyykkönen (2007a), it has by now become clear that the associations are important partners for the local authorities. While only scanty systematic information is available, what there is shows that the authorities, both local and national, have actively encouraged religious and cultural organisation. Funding and help in finding premises for activities is also common (Martikainen 2004a; Pyykkönen 2003; Saksela 2003). The first prayer room in the city of Turku, for instance, was provided to the local Muslims by an organisation under the auspices of the city's Cultural Office - the Interna- 
tional Meeting Point. The space soon proved to be too small, and the local authorities recommended that the Muslims organise themselves so that they could apply to the city for premises. This was in fact done, and a place was provided, although not without minor conflicts; at the same time the group was divided in two, separating Sunni and Shia Muslims, and one of the groups was left to find a space on its own (Martikainen 2000). This division is one example of the unintended consequences of governance, although there were other factors involved as well.

Auditing and evaluation are by definition part of funding procedures, but specific projects have also been formed toward that end, for instance the Promenio Project in the cities of Tampere and Turku (Promenio 2006). Much of this is encouraged by the local interpretation of the Integration Law, and its implementation thus aims at advancing the survival and adaptation of 'original cultures' and religion in the new context. The general expectations of the authorities include the hope that the associations will lead to participation and activity in these associations and in other, government-sponsored programmes. This is also explicitly stated in the Finnish Government's Migration Policy Programme, ratified 19 October 2006 (MOL 2006, 18).

In this sense immigrant empowerment and integration refer to becoming part of organised activities that are subject, if necessary, to control and advice. These techniques are created to form subjects that function within understandable settings based on national legislation, norms and tradition; the strategies adopted, however, sometimes fail to address the needs of the people in question. Hence it is a common observation that many projects fail in their explicit targets. People may not participate in as large numbers as hoped, or after initial enthusiasm the activities fade. Despite these shortcomings, however, we can safely state that during the last fifteen years a many-sided and complex system of governance directed at integration has been created. Voluntary associations have become an elementary part of the system (Pyykkönen 2007a).

'Forms of rationality' refers to 'more or less explicit, purposive attempts to organize and reorganize institutional spaces, their routines, rituals and procedures, and the conduct of actors in specific ways' (Dean 1999, 31-32). In other words, it refers to attempts to make the subjects to confirm to the rationality of government. What does this mean in the context of immigrant and Muslim associations? As the systemic structure of Islam differs - at least in a historical sense, if not that much in the globalised world (cf. Beyer 2006) - from that of the systemic position of religion in the 
late modern society of Finland, it is simply a question of domesticating ${ }^{8}$ Islam so that it conforms to national standards (cf. Allievi 2003c, 410). This, however, is more easily said than done. It is almost impossible to interfere with religious matters directly; questions of religious legitimacy, authenticity and authority would immediately arise following outside interference in core religious matters and values (cf. Johanssen 2006).

A crucial means in this endeavour is to engage in dialogue, creating platforms for discussion between the authorities and Muslim organisations, and encouraging the emergence of inter-religious dialogue. These discursive mechanisms are the most valuable means of reaching a consensus or at least shared ground on key issues. One of the most widely used discursive tactics is the distinction between 'religion' and 'culture', as a way of bypassing and explaining unpleasant, illegal or otherwise impractical traditions as part of the cultural baggage that can be explained away (cf. Baumann 1999). What we see here is that certain problematic issues are made the business of religious communities and their leaders, making them responsible for solving them and supporting them in this task. It is no trivial matter that the President of Finland has invited religious leaders to her office to discuss peaceful relations between religions and social cohesion (cf. Illman 2006).

In 2005, the Ombudsman for Minorities started to organise - or at least to propose - a national Muslim council in Finland. Invitations were sent to Finnish mosque communities and meetings were arranged. The invitation states the need for a representative body:

There are tens of thousands of Muslims in Finland and their number grows constantly. The Finnish society does not yet take enough into account matters of relevance to Muslims, because the society only takes into account those religions that have an official position. [...] A change to the situation would require cooperation between all Muslims living in Finland. Therefore the Office for the Ombudsman for Minorities invites you to a cooperation meeting on Monday, 12 September 2005. (OFM 2005, translation by the author.)

After a year of negotiations, the Islamic Council of Finland (Suomen Islamilainen Neuvosto r.y.; abbreviated SINE) was founded in November 2006 (SINE 2006). The Prime Minister's Office arranged financing for the newly

\footnotetext{
8 'Domestication' can have at least two meanings. First, it can refer to processes of adaptation, e.g., with regard to religious institutionalisation (LeVine 2005, 61). Second, it can refer to the 'taming' of a possible threat to social cohesion or security (McCutcheon 2005).
} 
established organisation (Volanen 2008). One main reason for organisation was that the state needed a body that was sufficiently representative so that general questions regarding Muslim integration could be jointly discussed and agreed upon. The approved statutes of the society state, among other things, that it will aim at countering religious extremism and radicalism in Finland. The eventual hope is that such platforms will become arenas for empowerment, integration and self-governance (Pyykkönen 2007a).

The difficulty, however, is how to maintain the religious legitimacy and secure the authority of the selected actors in the eyes of their followers. This is the main reason why such negotiations take a long time, as internal discussions are fundamental; it also explains why it has led to internal divisions among Muslim groups in many countries (Allievi 2003c, 386-388; Maréchal 2003a, 151-182). Not all people want the same thing. The role of governance, amidst such realities, is at least to maintain control of the situation. Nevertheless, it has been recognised that the hoped-for results can only be achieved though internal processes, so that the solutions offered will have religious validity. Muslim religious organisations and leaders are thus essential partners in the process. This is also the internal logic of the official understanding of integration and multiculturalism in Finland.

The fourth regime of practices is the formation of identities: 'they [the authorities] elicit, promote, facilitate, foster and attribute various capacities, qualities and statuses to particular agents' (Dean 1999, 32). It is thus a question of promoting rather than determining, of empowering more than commanding. Conferring status, as with the forms of rationality, helps to make things happen by providing opportunities for leadership, prestige and responsibility through various techniques of governance. The state hopes for the emergence of strong religious community leaders, not guerrilla or terrorist chiefs, and its implicit policy is aimed at fostering such developments. This includes the distinctions and identifications of different societal systems, where such authority is available, but without a threat to security. This is also why much of the seemingly naïve and idealistic ${ }^{9}$ discussion of the high ethical standards of all religions is promoted by both the religious and the secular authorities: it makes the distinction between good and evil explicit, creating boundaries between the righteous and the wrongdoers.

\footnotetext{
9 In much of the discussion of religions, the ethics and morals of particular religions are often represented in a highly idealised way. The same takes place in apologetics, where Our Religion is represented in an idealised manner, the Other's Religion by selecting the ethically most suspicious elements. Without ignoring the lofty ideals of many religions, they often bear only limited relation to the empirical situation.
} 
'Civilised religions' promote peace and are 'true religions'; they are not a threat to anyone, at least at the level of national security. The formation of authority, however, is no easy task, and it cannot be forced, at least not in the long run (cf. Johansen 2006).

In the above, I have discussed the various regimes of practices that have emerged to deal with the perceived problem of immigrant Muslims. There still remains the question of reform: what all these measures aim at. The above discussion has perhaps placed too much emphasis on the agency of state and local authorities. Many of these developments have presumably taken place without much careful consideration, as natural reactions to changed conditions; there has not necessarily been a hidden agenda, as might be suggested by a hasty reading of the main argument. This does not make the analysis weaker; on the contrary. If we take seriously the existence of mentalities of rule - governmentality - it should be no surprise that events take place in this manner. It follows the logic of 'doing as has been done before': it is the internal, non-reflective nature of governance. However, it is also related to agency, and as we have seen a number of actors in various parts of the administrative system have taken the initiative, sometimes without mutual awareness. Actually, one of the striking features of the authorities' activities in relation to Islam, so far at least, has been the lack of inter-administrative contact in many cases. Each societal (sub)system seems to deal with the issues on the basis of its own premises.

Hence, the need and search for reform is inherent in governance. Ultimately, it is not so much a question of a certain desired outcome, let us say social cohesion, national security or migrant empowerment. It is more a question of being able to deal with anomalies, to domesticate, to manage, to normalise and to internalise new elements, as well to expel, to externalise and to exclude. We must therefore also critically ask about the possible outcomes of these processes of governance, the governmentalisation of Islam and Muslims in Finland. Positive results are not systemic features of government; there may also be unintended side-effects of all kinds.

\section{Discussion}

This article has postulated that both the local and the national authorities have not been mere bystanders with regard to Muslim incorporation into Finnish society. Following Dean's analytical model and Pyykkönen's techniques of governance, we can analyse how the authorities have encouraged the formation of Muslim communities and especially their formalisation and incorporation into society. This has opened up access to funding that is 
controlled by the authorities themselves. Attempts have also been targeted towards supervising the running of these associations as well as creating networks among different actors. All of these activities are in accordance with the Integration Law, and with its spirit: promoting the advancement of 'original cultures'. Based on numerous discussions with Finnish Muslim activists, I can confirm that participation in these networks is considered important, but that there is also a general expectation that they should open up more opportunities, either in the form of funding or by other means.

It is quite apparent that all sides benefit from co-operation, so why should we find room for critical remarks? First of all, it is clear that this 'domestication' of Islam in Finland is not without consequences for the internal dynamics of Finnish Muslim communities. Certain people are raised to important positions, where they act on behalf of others. Second, the processes of migrant adaptation are quite complex, and there is no way to estimate beforehand how this guided integration will affect the community's future development. Third, the distribution of power among different actors is highly unequal, and offers opportunities for its misuse. While I am not aware of such events, this demands high ethical standards of those with greater power. Fourth, the stress on the religious factor may in this case disadvantage people of Muslim background who hold different views from those who act as their spokespersons. The element of democratic representation may be forced by circumstances and does not necessarily follow the internal dynamics. Fifth, the active outside involvement may lead to the essentialisation of 'Muslim culture and religion', while disregarding the inherent dynamism of the settlement process. In this sense, the authorities are actually actively involved in creating 'cultural others'. We may ask whether strong state involvement can lead to the clientisation of immigrants as well as to a pathologisation of cultural and social difference; with time, these processes may create permanent structures that support the status quo, in which many people of immigrant background are in a disadvantaged position (Kamali 1997). While the migrants themselves may or may not support the authorities' agenda, the unequal distribution of power can also induce unwelcome side-effects. This is one of the dilemmas of the policies of Multikulti.

The perspective of governmentalisation is a fruitful tool for analysing the inherent power structures in modern societies. While this article has attempted to cast new light on this complex phenomenon with regard to the Muslims in Finland, I take it for granted that further research on the topic will show a more nuanced picture of these developments, illuminating new actors in the field and questioning some of established notions 
of migrant integration research. An analysis of governmentalisation can help to make the authorities' agendas explicit and open up room for critical debate: are their means and ends legitimate, and do they belong in a democratic society?

Bibliography

\section{Allievi, Stefano}

2003a Muslims and Politics. - Brigitte Maréchal \& Stefano Allievi \& Felice Dassetto \& Jørgen Nielsen (eds), Muslims in the Enlarged Europe, 183-213. Leiden: Brill.

2003b Relations and Negotiations: Issues and Debates on Islam. - Brigitte Maréchal \& Stefano Allievi \& Felice Dassetto \& Jørgen Nielsen (eds), Muslims in the Enlarged Europe, 331-68. Leiden: Brill.

2003c Relations between Religions. - Brigitte Maréchal \& Stefano Allievi \& Felice Dassetto \& Jørgen Nielsen (eds), Muslims in the Enlarged Europe, 369-414. Leiden: Brill.

\section{AlSayyad, Nezar \& Manuel Castells (eds)}

2002 Muslim Europe or Euro-Islam: Politics, Culture, and Citizenship in the Age of Globalization. Lanham: Lexington Books.

Archer, Toby

2004 Kansainvälinen terrorismi ja Suomi. (UPI-raportti 7/2004.) Helsinki: Finnish Institute of International Affairs.

\section{Bader, Veit}

2007 Secularism or Democracy? Associational Governance of Religious Diversity. Amsterdam: Amsterdam University Press.

\section{Baumann, Gerd}

1999 The Multicultural Riddle. London: Routledge.

\section{Baumann, Martin}

2002 Migrant Settlement, Religion and Phases of Diaspora. - Migration 33/34/35, 93-117.

\section{Beyer, Peter}

2006 Religions in Global Society. London: Routledge.

\section{Buijs, Frank \& Jan Rath}

2005 Muslims in Europe: The State of Research. IMISCOE Working Papers, http://www.imiscoe.org/publications/workingpapers/documents/ MuslimsinEurope-Thestateofresearch.pdf. [Accessed 27.8.2006.] 
Byrnes, Timothy A. \& Peter J. Katzenstein (eds)

2006 Religion in an Expanding Europe. Cambridge: Cambridge University Press.

Castles, Stephen \& Mark Miller

2003 The Age of Migration: International Population Movements in the Modern World. Third Edition. New York: Palgrave Macmillan.

CBMI=Commission on British Muslims and Islamophobia

2004 Islamophobia: Issues, Challenges and Action. Stoke on Trent: Trentham Books.

Creutz, Karin \& Heidi af Heurlin \& Riikka Lehtonen

2002 Islam och pressen - Synen på islam i Hufvudstadsbladets och Helsingin Sanomatsledare; november 2000 - oktober 2001. - Tom Sandlund (ed.), Etnicitetsbilden i finlandssvenska medier, 207-37. Helsinki: Svenska social- och kommunalhögskolan vid Helsingfors universitet.

Dean, Mitchell

1999 Governmentality: Power and Rule in Modern Society. London: Sage.

Eade, John (ed.)

1997 Living the Global City: Globalization as a Local Process. London: Routledge.

Ebaugh, Helen Rose \& Janet Saltzman Chafetz (eds)

2000 Religion and the New Immigration: Continuities and Adaptations in Immigrant Congregations. Walnut Creek: Altamira.

EUMC=European Monitoring Centre on Racism and Xenophobia

2002 Summary Report on Islamophobia in the EU after 11 September 2001. Vienna: European Monitoring Centre on Racism and Xenophobia.

2006 The Impact of 7 July 2005 London Bomb Attacks on Muslim Communities in the EU. Vienna: European Monitoring Centre on Racism and Xenophobia.

EYID=European Year of Intercultural Dialogue

2007 European Year of Intercultural Dialogue website, http://www.interculturaldialogue2008.eu/. [Accessed 22.11.2007.]

Featherstone, Mike \& Scott Lash (eds)

1999 Spaces of Culture. London: Sage.

Featherstone, Mike \& Scott Lash \& Roland Robertson (eds)

1995 Global Modernities. London: Sage.

Forsander, Annika

2002 Luottamuksen ehdot: Maahanmuuttajat 1990-luvun suomalaisilla työmarkkinoilla. Helsinki: Väestöliiton Väestöntutkimuslaitos. 


\section{Foucault, Michel}

1991 Governmentality. - Graham Burchell \& Colin Gordon \& Peter Miller (eds), The Foucault Effect: Studies in Governmentality, 87-104. London: Harvester Wheatsheaf.

Haddad, Yvonne Yazbeck \& Jane Smith (eds)

2002 Muslim Minorities in the West: Visible and Invisible. Walnut Creek: Altamira.

\section{Hannerz, Ulf}

1996 Transnational Connections. London: Routledge.

Harviainen, Tapani

1999 The Northernmost Turk Community - A Case of Euro-Islam in Finland. - International Conference: Atatürk and Modern Turkey, 723-30. Ankara, Ankara Üniversitesi Basımevi.

\section{Illman, Ruth}

2006 Interreligious Solidarity of Being: Similarity, Difference and Ethics in Abrahamic Dialogue in Finland, a paper presented at the conference 'Encountering the Other: Religious Arguments for Tolerance', University of Notre Dame, Indiana, USA, 24.4.2006.

\section{IOM=International Organization for Migration}

2007 Integration: A Multifaith Approach: Project Overview. Unpublished letter. Organization for Migration, Regional Office for the Nordic and Baltic States.

\section{Ireland, Patrick}

2004 Becoming Europe: Immigration, Integration, and the Welfare State. Pittsburgh: University of Pittsburgh Press.

\section{Jaakkola, Magdalena}

2005 Suomalaisten suhtautuminen maahanmuuttajiin vuosina 1987-2003. (Työpoliittinen tutkimus 286.) Helsinki: Työministeriö.

\section{Jacobsen, Knut \& P. Pratap Kumar (eds)}

2004 South Asians in the Diaspora: Histories and Religious Traditions. Leiden: Brill.

\section{JEMS=Journal of Ethnic and Migration Studies}

2007 Special Issue: Governing Islam in Western Europe: Essays on Governance of Religious Diversity. - Journal of Ethnic and Migration Studies $33(6)$.

\section{Johansen, Birgitte Schepelern}

2006 Islam at European Universities. Report II, University of Copenhagen Research Priority Area 'Religion in the 21st Century'. Copenhagen: University of Copenhagen. 


\section{Kamali, Masoud}

1997 Distorted Integration: Clientization of Immigrants in Sweden. Uppsala: Uppsala Centre for Multiethnic Research, Uppsala University.

\section{Kivisto, Peter}

2002 Multiculturalism in a Global Society. Oxford: Blackwell.

Klausen, Jytte

2005 The Islamic Challenge: Politics and Religion in Western Europe. Oxford: Oxford University Press.

Kraus, Peter

2003 Cultural Pluralism and European Polity-Building: Neither Westphalia nor Cosmopolis. - Journal of Common Market Studies 41 (4), 665-86.

Kääriäinen, Kimmo \& Kati Niemelä \& Kimmo Ketola

2005 Religion in Finland: Decline, Change and Transformations of Finnish Religiosity. Tampere: Church Research Institute.

Lehtinen, Isra

2007 Miten viranomaiset huomioivat muslimit: Ohjeet ja käytäntö ihmisoikeusnäkökulmasta. - Uskonnontutkija 1/2007.

\section{Lepola, Outi}

2000 Ulkomaalaisesta suomenmaalaiseksi. Helsinki: SKS.

\section{LeVine, Sarah}

2005 The Theravada Domestic Mission in Twentieth-Century Nepal. - Linda Learman (ed.), Buddhist Missionaries in the Era of Globalization, 51-76. Honolulu: University of Hawai'i Press.

\section{Maasilta, Mari \& Juho Rahkonen \& Pentti Raittila}

2008 Islam suomalaisissa joukkoviestimissä. Julkaisuja A 103. Tampere: Tampereen yliopisto, Tiedotusopin laitos.

\section{Maréchal, Brigitte}

2003a Institutionalisation of Islam and Representative Organisations for Dealing with European States. - Brigitte Maréchal \& Stefano Allievi \& Felice Dassetto \& Jørgen Nielsen (eds), Muslims in the Enlarged Europe, 151-82. Leiden: Brill.

2003b Modalities of Islamic Instruction. - Brigitte Maréchal \& Stefano Allievi \& Felice Dassetto \& Jørgen Nielsen (eds), Muslims in the Enlarged Europe, 19-77. Leiden: Brill.

2003c Mosques, Organisations and Leadership. - Brigitte Maréchal \& Stefano Allievi \& Felice Dassetto \& Jørgen Nielsen (eds), Muslims in the Enlarged Europe, 79-150. Leiden: Brill.

Maréchal, Brigitte \& Stefano Allievi \& Felice Dassetto \& Jørgen Nielsen (eds)

2003 Muslims in the Enlarged Europe. Leiden: Brill. 


\section{Martikainen, Tuomas}

2000 Muslim Groups in Turku. - Journal of Muslim Minority Affairs 20 (2), 329-45.

2004a Immigrant Religions in Local Society: Historical and Contemporary Perspectives in the City of Turku. Turku: Åbo Akademi University Press.

2004b Islam i Finland. - Svensk religionshistorisk årsskrift 13, 105-23.

2007 Maahanmuuttajaväestön sukupuolittuneisuus, perheellistyminen ja sukupolvisuus. - Tuomas Martikainen \& Marja Tiilikainen (eds), Maahanmuuttajanaiset: Kotoutuminen, perhe ja työ, 38-67. (Väestöntutkimuslaitoksen julkaisusarja D 46/2007.) Helsinki: Väestöliiton Väestöntutkimuslaitos.

Forthcoming Finland. - Göran Larsson (ed.), Islam and Muslims in the Nordic and Baltic Countries. London: Kegan \& Paul.

McCutcheon, Russell

2005 Religion and the Domestication of Dissent: Or, How to Live in a Less Than Perfect Nation. London: Equinox Publishing.

\section{Ministry of the Interior}

2004 A Safer Community - Internal Security Programme: Summary. Helsinki: Ministry of the Interior.

\section{MOL=Ministry of Labour}

2006 Government Migration Policy Programme: Government Resolution 19.10.2006. (Työhallinnon julkaisu 371.) Helsinki: Ministry of Labour.

\section{Männistö, Anssi}

1999 Islam länsimaisessa hegemonisessa diskurssissa: Myyttis-ideologinen ja kuva-analyyttinen näkökulma sivilisaatioiden kohtaamiseen. Tampere: Tampereen yliopisto, Yhteiskuntatieteellinen tiedekunta, Rauhan- ja konfliktintutkimuskeskus.

\section{Nielsen, Jørgen}

1995 Muslims in Western Europe. Second edition. Edinburgh: Edinburgh University Press.

\section{Nökel, Sigrid \& Levent Tezcan}

2005 Islam and the New Europe: Continuities, Changes, Confrontations. Bielefeld: Transcript.

OFM=Office for Ombudsman for Minorities

2005 Kutsu yhteistyökokoukseen 12.09.2005. Unpublished letter signed by the Ombudsman for Minorities.

\section{PEW=Pew Research Center}

2006 The Pew Global Attitudes Project: 2006, The Great Divide: How Westerners and Muslims View Each Other. Washington: Pew Research Center. 
Poole, Elisabeth \& John Richardson (eds)

2006 Muslims and the News Media. London: I. B. Tauris.

\section{Promenio}

2006 Promenio website, http://www.promenio.net/. [Accessed 27.8.2006.]

\section{Pyykkönen, Miikka}

2003 Integraatio ja maahanmuuttajien yhdistystoiminta. - Sakari Hänninen \& Anita Kangas \& Martti Siisiäinen (eds), Mitä yhdistykset välittävät: Tutkimuskohteena kolmas sektori, 89-120. Jyväskylä: Atena.

2007a Integrating Governmentality: Administrative Expectations for Immigrant Associations in Finland. - Alternatives 32, 197-224.

2007b Järjestäytyvät diasporat: Etnisyys, kansalaisuus, integraatio ja hallinta maahanmuuttajien yhdistystoiminnassa. (Jyväskylä Studies in Education, Psychology and Social Research 306.) Jyväskylä: Jyväskylän yliopisto.

Robbers, Gerhard (ed.)

2005 State and Church in the European Union. Second Edition. Baden-Baden: Nomos.

Roy, Olivier

2004 Globalized Islam: The Search for a New Ummah. New York: Columbia University Press.

Ruhanen, Milla \& Tuomas Martikainen

2006 Maahanmuuttajaprojektit: hankkeet ja hyvät käytännöt. (Katsauksia E 22/2006.) Väestöliitto, Väestöntutkimuslaitos.

\section{Sakaranaho, Tuula}

2006 Religious Freedom, Multiculturalism, Islam: Cross-reading Finland and Ireland. Leiden: Brill.

\section{Sakaranaho, Tuula \& Anne Alitolppa-Niitamo \& Tuomas Martikainen \& Marja Tiilikainen}

2004 Religion in Migration: Studies on Muslims in Finland. - Vesa Puuronen \& Antti Häkkinen \& Anu Pylkkänen \& Tom Sandlund \& Reetta Toivanen (eds), New Challenges for the Welfare Society, 124-39. Joensuu: University of Joensuu, Karjalan tutkimuslaitos.

\section{Sakaranaho, Tuula \& Heikki Pesonen}

1999 Muslimit Suomessa. Helsinki: Yliopistopaino.

\section{Saksela, Sanna}

2003 Mångkulturella organisationer och invandrarorganisationer i Finland. - Flemming Mikkelsen (ed.), Invandrerorganisationer i Norden, 235-81. Copenhagen: Nordiska ministerrådet. 
SINE=Suomen islamilainen neuvosto r.y.

2006 Suomen islamilainen neuvosto r.y. Unpublished letter reporting the foundation of the society.

\section{Stepick, Alex}

2005 God is Not Apparently Dead: The Obvious, the Emergent, and the Still Unknown in Immigration and Religion. - Karen Leonard \& Alex Stepick \& Manuel Vasquez \& Jennifer Holdaway (eds), Immigrant Faiths: Transforming Religious Life in America, 11-37. Walnut Creek: Altamira.

\section{SUPO}

2005 Finnish Security Police: Annual Report 2005, English Summary, http://www.poliisi.fi/poliisi/supo/home.nsf/pages/indexeng > Annual Report 2005. [Accessed 27.8.2006.]

\section{Tibi, Bassam}

2002 The Challenge of Fundamentalism: Political Islam and the New World Disorder. Updated edition. Berkeley: University of California Press.

\section{Volanen, Risto}

2008 Interview with State Secretary Risto Volanen, Prime Minister's Office, 4.3.2008.

\section{Warner, R. Stephen \& Judith G. Wittner (eds)}

1998 Gatherings in Diaspora: Religious Communities and the New Immigration. Philadelphia: Temple University Press. 
